Laird, R. Jr. \& Walker-Love, J. (1962). F. agric. Sci. 59, 233.

Lambourne, L. J. (1956), N.Z.F. Sci. Tech. 37A, 555.

Lambourne, L. J. (1961). Proc. N.Z. Soc. Anim. Prod. 21, 92.

Langlands, J. P., Corbett, J. L., McDonald, I. \& Reid, G. W. (I963). Anim. Prod. 5, Ir.

Line, C. (1961). Proc. int. Grassl. Congr. virr. Reading, p. 598.

McMeekan, C. P. (1958). Proc. N.Z. Soc. Anim. Prod. 18, 32.

McMeekan, C. P. (1961). Proc. int. Grassl. Congr. vill. Reading, p. 2 r.

Moore, I. \& Williams, H. T. (1961). F. Brit. Grassl. Soc. 16, 206.

Mott, G. O. (1961). Proc. int. Grassl. Congr. viII. Reading, p. 606.

National Agricultural Advisory Service. (1962). Bridget's exp. Husb. Farm Rep. p. 2 I.

Sjollema, B. (1950). F. Brit. Grassl. Soc. 5, 179.

Smith, E. P. \& Keyes, E. A. (1959). F. Dairy Sci. 42, 137.

Vik, E. (1956). Forskn. Fors. Landbr. 7, 109.

Waite, R., Castle, M. E. \& Watson, J. N. (1959). F. Dairy Res. 26, I73.

Waite, R., Holmes, W. \& Boyd, J. (r952). F. agric. Sci. 42, 3 I4.

Wallace, L. R. (1948). F. agric. Sci. 38, 93 .

\title{
Some factors affecting the efficient utilization of conserved grass*
}

\section{By J. C. Murdoch, National Institute for Research in Dairying, Shinfield, Reading}

The efficient utilization of conserved grass is dependent on several factors, and these include the nutritive value of the product and its intake by the animals to which it is given, both of these factors being influenced by the crop which is conserved and the efficiency of preservation. The method of conservation (i.e. by ensilage or haymaking) also has an effect on utilization, as have supplementary foods given with the conserved product. The loss of nutrients associated with the conservation process must also be considered, since the extent of this loss determines the quantity of nutrients that will be available in the final product.

The most important methods of conservation in Britain are ensilage and haymaking, and discussion will be limited to these two methods.

\section{The loss of nutrients associated with the conservation process}

Losses in making silage. The sources of nutrient loss in ensilage are surface waste, plant respiration, bacterial fermentation and effluent from the silage. The losses associated with plant respiration and the subsequent fermentation are often referred to as being unavoidable, but though it may be true when applied to conditions in any one mass of silage, the term is incorrect in general application. It has been shown clearly that the type of fermentation in silage has a marked effect in determining nutrient losses (Murdoch \& Holdsworth, 1958), the losses being higher when the volatile fatty acid content of the silage is high relative to that of the lactic acid. Many factors influence the fermentation in silage, and the most important appear to be the sugar and the dry-matter content of the herbage being ensiled (Murdoch, I $96 \mathrm{I}$ ).

There can be an appreciable loss of nutrients in the effluent from the silage, the loss being determined to some extent by pressure on the silage and the additives used

\footnotetext{
* Read at the joint meeting of The Nutrition Society and the British Grassland Society in London on 5 December 1963. Also published in the fournal of the British Grassland Society, Vol. 19, No. I, March 1964.
} 
when the crop is being ensiled (Perkins \& Pratt, I95I; Gordon, Irvin, Melin, Wiseman \& McCalmont, 1957). The dry-matter content of the crop being ensiled, however, exerts the greatest influence on nutrient losses in the effluent, as it appears that losses are negligible when the dry-matter content of the herbage ensiled exceeds $25 \%$ (Murdoch, 1954; Allred \& Kennedy, 1956).

Surface waste in silage can result in very high nutrient losses, as is shown by results from experiments in which farm-scale silos have been used. Total losses of the order of $40-50 \%$ of the dry matter ensiled have been reported (Sears \& Goodall, 1947; Culpin, 1960; Watson \& Nash, I960), results which compare unfavourably with dry-matter losses of $10-25 \%$ obtained in other trials (Brown \& Smyth, 1958; Gordon, Kane, Derbyshire, Jacobson, Melin \& McCalmont, 1959). The discrepancy between these results is due apparently to a difference in the extent of surface waste occurring in the silages, and it has been shown that, as silage is increasingly exposed to the ingress of air, dry-matter losses are progressively increased (Sears \& Goodall, I947; Culpin, 1960).

Losses in making hay. Nutrient losses in haymaking are caused by plant respiration, mechanical damage, leaching by rain and adverse storage conditions. Except for carotene, of which $70 \%$ may be lost (Kon \& Thompson, 1940), losses during storage appear to be of a low order (Watson, Ferguson \& Horton, I937; Murdoch, Foot, Head, Holdsworth, Hosking \& Line, 1959), unless there is extensive heating in the stack (Geering, 1939; Monroe, Hilton, Hodgson, King \& Krauss, 1946). The loss during storage appears to be directly related to the moisture content of the hay when it is stacked (Monroe et al. I946; Dijkstra, 1947).

Wiegner (1932) has reported results from a series of experiments, which give some indication of the relative importance of plant respiration, mechanical damage and leaching by rain in losses incurred by natural drying of hay. The loss of dry matter and starch equivalent was low when no losses due to mechanical treatment or leaching were involved. Mechanical damage without rain falling on the hay increased the loss of starch equivalent by $16 \%$, and there was a further increase of ${ }_{1} 6 \%$ in the loss of starch equivalent when the hay was subjected to frequent showers of rain. It appears that both mechanical damage and leaching losses only reach serious proportions when the dry-matter content of the herbage drying in the field is high (Dobie, Jones \& Zscheile, I953; Watson \& Nash, 1960).

Conditioning machinery can be used to accelerate the rate of drying of hay (Murdoch \& Bare, 1960; Shepperson, Grundey \& Wickens, I 962), thus reducing the length of time during which the hay is exposed in the field, but such treatment may result in an increase in nutrient loss, presumably due to mechanical damage (Murdoch \& Bare, 1960; Shepperson et al. 1962). Generally, however, the loss caused by conditioning machinery is less than might be expected in badly weathered hay. The technique of barn-drying hay results in consistently low nutrient losses partly because of the reduction in the weather risk, but also because the hay is removed from the field before it becomes vulnerable to mechanical damage (Carter, I 960 ; C. Culpin, 1962). 
Comparison of silage and hay. Results from any one comparison of methods of conservation can be misleading, since conditions may be adverse for one of the methods. For example, nutrients are preserved more efficiently in barn-dried hay and silage than in field-cured hay when the latter has been made in adverse weather conditions, but there were only small differences in losses incurred by the conservation methods when the field-cured hay was made in good weather (Shepherd, Wiseman, Ely, Melin, Sweetman, Gordon, Schoenleber, Wagner, Campbell, Roane \& Hosterman, I954). Results from a number of trials, mainly under American conditions, have been summarized by Carter (1960) and, generally, the loss of dry matter was higher in field-cured hay than in silage, and barn-drying of hay was slightly more efficient than ensilage in preserving nutrients. When field-cured hay was made in poor weather conditions, nutrient losses were considerably greater than with the other conservation methods. These conclusions may not be wholly applicable to Britain, since the losses quoted from American sources for silage appear to be lower than they would be in this country, where some data indicate that the loss of dry matter in silage-making is considerably higher than in barn-drying hay (S. Culpin, 1962).

\section{The nutritive value of conserved products}

Effect of the crop being conserved. The nutritive value of a conserved product depends to a great extent on the crop from which it is made, since it has been shown that the digestibility of silage and hay closely resembles that of the original herbage (Shepperson, 1960; Harris \& Raymond, I963). The results obtained in these trials show that two important factors determining the digestibility of hay and silage are the stage of maturity at which the crop is harvested and the species of grass.

There is a considerable volume of data to show that the digestibility of grass, and the conserved products made from it, decreases progressively after ear emergence has taken place (Shepperson, I960; Harris \& Raymond, I963). It has also been shown that the net energy of hay decreases as the crop from which it is made increases in maturity, the decrease being more marked when the energy is used for production than for maintenance (Armstrong, 1960). These changes in digestibility are reflected in animal production, since higher milk yields (Trimberger, Kennedy, Turk, Loosli, Reid \& Slack, I955; Castle, Drysdale \& Watson, I962; Murdoch \& Rook, I963) and live-weight gains (Dodsworth \& Campbell, I953) were obtained when silage or hay made from immature grass was given to the animals.

Differences in digestibility have also been found between conserved products made from different species of grass, although the grasses had been harvested at the same stage of maturity. One outstanding difference is that existing between perennial ryegrass (Lolium perenne L.) and cocksfoot (Dactylis glomerata L.), cocksfoot invariably having a lower digestibility than ryegrass (Harris \& Raymond, 1963), and again this difference is reflected in the milk production obtained from hay made from these grasses (Castle et al. 1962). There are also some data which indicate that lucerne (Medicago sativa L.) has a lower digestibility than the grasses (Harkess, 1963), 
and lower milk yields have been obtained from lucerne silage than from grass silage (Murdoch, I 962a).

Effect of efficiency of conservation. High temperatures in silage or hay during the storage period result in a marked decrease in the digestibility of these products, the protein fraction being particularly affected (Watson \& Nash, I960). Silage with a high $\mathrm{pH}$ value will also have a lower digestibility than one that has been well preserved, which results in higher milk yields in favour of the silage with the satisfactory fermentation (Newlander, Ellenberger, Camburn \& Jones, I940; Murdoch, I962a). Shepperson ( 1960 ) has shown that the digestibility of hay can be influenced considerably by various haymaking techniques.

Effect of previous treatment of the crop. Higher yields of grass are obtained when nitrogen fertilizer is applied, but this treatment also results in changes in the chemical composition of the herbage (Hood, I957). When fertilizer nitrogen is applied to the crop there is an increase in the nitrogen and nitrate content and a decrease in the dry-matter and sugar content, particularly of fructosan, of the herbage (Ferguson \& Terry, 1957; Gordon, Decker \& Wiseman, 1962; Nowakowski, 1962). Apart from any nutritional significance, these changes can have a marked, adverse effect on the fermentation taking place in silage (Gordon, Derbyshire \& Jacobson, 1963a). There is no clear-cut association between level of nitrogen fertilizer application to grass and the digestibility of the silage made from it, but it appears that the decrease in digestibility with stage of maturity may be less marked when nitrogen fertilizer has been applied to grass (Gordon et al. 1963a).

Top-dressing the grass with nitrogen fertilizer $7^{-14}$ days before harvesting increases the crude-protein content of hay, the contents of digestible crude and true protein being increased to a similar extent, but no effect being observed on the starch equivalent value (Ferguson, I948).

Comparison of silage and hay. Clearly the conditions under which the conserved products are made will have a marked effect on the nutritive value of the product and on animal production. When hay and silage are made at the conventional times, the nutritive value of hay will be lower than that of silage if both products have been preserved satisfactorily (Trimberger et al. 1955). The lower nutritive value of the hay will be reflected in milk production (Trimberger et al. 1955; Presthegge, 1959; Murdoch \& Rook, 1963) and in carcass weight (Presthegge, 1959) when an equal quantity of dry matter in the form of either hay or silage is given to the animals. This is to be expected, since hay will normally be made from grass at a more mature stage of growth than will silage, the digestibility of the original crop being lower for hay (Minson, Raymond \& Harris, 1960).

Although there are considerable practical difficulties, hay can be made from grass at the same stage of maturity as silage. Evidence is conflicting as to the relative value of hay and silage made from herbage at the same stage of maturity, and it is often difficult to determine whether differences are due to the conservation method per se or to the relative efficiency with which the methods of conservation have been carried out. There are data available which indicate that an advantage in terms of digestibility can exist for either silage or hay (Trimberger et al. I955; S. Culpin, 
I962; Gordon, Derbyshire, Jacobson \& Wiseman, I963 $b$; Murdoch \& Rook, I963) but, in general, differences in digestibility are small (Carter, r960).

A similar conflict of evidence is found in comparisons in which silage and hay have been evaluated in terms of milk production. Carter ( 1960 ), summarizing American data from direct comparisons of hay and silage, has reported that no significant differences in milk yield were obtained between hay and silage when both products were preserved satisfactorily. This conclusion agrees with some results obtained from trials in Britain (Murdoch \& Rook, 1963 ). On the other hand, higher milk yields have been obtained with silage than with hay (Horwood \& Wells, 1936; Pratt \& Holdaway, I 943; Trimberger et al. 1955; Presthegge, I959; Brown, I962), but these results which show an advantage for silage may have been due to the conditions of the experiments. For example, part of the hay given to the animals in some trials was from a different source than the silage (Horwood \& Wells, 1936; Pratt \& Holdaway, 1943), and in other trials the hay was harvested about a week later than the silage (Pratt \& Holdaway, I943) or had been made in poor weather conditions (Brown, 1962).

It is of interest, however, that Ekern \& Reid ( $\left.196_{3}\right)$ have found a greater mean retention of energy with silage than with hay, although both products were made from herbage at the same stage of maturity and had almost identical gross energy values, but there were large differences among the estimated means and differences were not significant.

\section{The intake of conserved products}

There are many factors which affect the voluntary intake of a roughage and these have been examined in detail by Campling (1964).

Dry-matter content of the roughage. One of the main factors determining the voluntary intake of a roughage is its dry-matter content, or some factor in the roughage closely associated with it. There is a general agreement that the dry-matter intake of silage increases with increasing dry-matter content (Murdock, Hodgson \& Harris, 1958; Brown, I960; Moore, Thomas \& Sykes, 1960; Murdoch, 1960, 1962b), and that the intake of hay is greater than that of high-moisture silage (Moore et al. r960; Slack, Kennedy, Turk, Reid \& Trimberger, I $960 b$; Gordon, Derbyshire, Wiseman, Kane \& Melin, I96I; Murdoch \& Rook, 1963). In some trials there has been little or no difference in the dry-matter intake of low-moisture silage and hay (Shepherd et al. 1954; Gordon et al. $1963 b)$, but appreciable differences have been reported in others (Moore et al. 1960; Gordon et al. 196r).

There is, however, considerable variation in results when attempts have been made to assess the increase in dry-matter intake in terms of production. Increases in milk yield (Moore et al. 1960; Gordon et al. 1961; Brown, Hillman, Lassiter \& Huffman, I963; Murdoch \& Rook, I963) and in live-weight gain (Dodsworth \& Campbell, I953; Newlander \& Riddell, I957; Murdock et al. 1958; Moore et al. 1960) have been found consistent with an increase in dry-matter intake with wilted silage or hay, but some results showed no increase in production (Brown, I960; Slack et al. I960b; Brown et al. 1963). 
Digestibility of the roughage. It has been clearly demonstrated that voluntary intake will be higher as the nutritive value of the roughage increases (Reid, Kennedy, Turk, Slack, Trimberger \& Murphy, I959; Slack et al. 1960b; Blaxter, Wainman \& Wilson, 1961), and that there will be an increase in milk yield (Reid et al. 1959; Slack et al. 1960b) and in live-weight gain (Blaxter et al. 196I) due to the combined effect of higher intake and the higher nutritive value of the roughage.

Efficiency of preservation. Little information is available on the effect on intake of the efficiency of preservation of a conserved product. There is some evidence that hay that has been made in poor weather conditions will be eaten less readily than hay that has been well made (Shepherd $e t$ al. I954), but it is only partly supported by results from another series of trials (Turk, Morrison, Norton \& Blaser, I95 I). A silage that has been poorly preserved will not be as acceptable to animals as one that has been well preserved (Newlander et al. I940; Allred, Kennedy, Wittwer, Trimberger, Reid \& Loosli, I955; Gordon et al. 1963a), and the preservative used in making the silage may also adversely affect intake (Allred et al. 1955; Bratzler, Cowan \& Swift, I955; McCarrick, I963).

Processing roughages. Minson (1962) has summarized the results of experiments in which ground and pelleted roughages have been compared with the roughage in a long form, and concludes that the processed roughages will generally have a lower digestibility of dry matter and crude fibre, but despite this will differ little in net energy because of the lower energy loss in urine, methane and heat with the ground roughage. Grinding and pelleting of roughage has usually resulted in an increase in intake and live-weight gain, but the response appears to be related to the quality of the unprocessed roughage, being larger with poor-quality roughages. Only small increases in milk yield have been observed when ground and pelleted roughage has been given, this probably being due to the high quality of the original roughage, but a depression in the fat content of the milk has been found, particularly when the roughage was finely ground.

Wafering, that is compressing long or chopped hay into wafers or cubes, may reduce digestibility of dry matter, but appears to have little effect on consumption, live-weight gain, milk yield or the fat content of milk (Minson, I962).

Reducing the length of hay by chopping appears to have little effect on intake (Slack, Kennedy, Turk \& Boyce, 1960a), but there are some reports which indicate that when the length of silage is reduced there is an increase in intake with a resulting increase in production (Morrison, 1960; Harris \& Raymond, 1963).

\section{The associative effects of giving other foods with roughages}

The effect of giving other foods with conserved products has been studied in considerable detail, and can only be dealt with briefly.

The intake of a conserved product can be modified to a marked extent by the foods given with it. Examples of this effect are the addition of hay to silage rations causing an increase in total dry-matter intake (Pratt \& Conrad, 1957; Brown et al. I 963$)$, and a decrease in roughage intake when supplementary concentrates are given (Brown, 1960; Slack et al. 1960b; Blaxter et al. 1961). Results from some trials suggest 
that concentrate supplementation has a more marked effect on the intake of roughage with a high digestibility than with poorer-quality roughage (Blaxter et al. 196r). It has also been shown that the lower the protein content of the concentrate the greater will be the depression in roughage intake (Murdoch, 1962c).

Supplementary concentrates can also have a marked effect on the digestibility of a roughage, as it has been shown that the apparent digestibility of cellulose and protein of hay can be depressed by starch supplements, but protein supplements had no effect on cellulose digestibility (Head, 1953).

A relationship has been observed between the foods given to animals and the proportion of acetic, propionic and butyric acids formed in the rumen (Shaw, I959; Bath \& Rook, 1962; Ekern \& Reid, 1963), and Rook (1961) has shown that these volatile fatty acids have specific effects on milk yield and composition, and they may also affect live-weight gain (Thomson, 1963). These changes in the proportion of ruminal volatile fatty acids explain some of the variations in production that can occur with certain rations, examples being the depression of the fat content of the milk when finely ground hay is given to cows or when the proportion of roughage in the diet is low compared to concentrates (Rook, I961). Such changes may also provide an explanation for other alterations in milk composition, which include the lower solids-not-fat content of milk when silage made from immature grass is given to cows (Murdoch \& Rook, 1963 ) and the increase in the fat content of the milk of cows given silage that had poorly fermented (Murdoch, 1962a).

\section{The yield of nutrients from a given area}

The yield of nutrients as affected by the conservation process is a direct function of the nutrient losses associated with the process (see Trimberger et al. 1955; Slack et al. 1960a; S. Culpin, 1962).

The yield of nutrients is also influenced by the stage of maturity at which the crop is harvested, yield of dry matter and of digestible nutrients increasing with maturity (Watson et al. 1937; Trimberger et al. 1955; Minson et al. 1960; Blaxter $\&$ Wilson, 1963$)$. Although there is a considerable increase in the yield of dry matter after ear emergence, the yield of digestible nutrients increases at a much slower rate and, indeed, may decrease at a late stage of maturity (Minson et al. 1960 ), this being due to the rapid decline in the digestibility of the herbage. When the contribution to nutrient output made by the aftermath following early harvesting of the crop is taken into account, the marked difference in dry-matter yield between early- and latecut crops still exists, but output of digestible nutrients may be only slightly greater for the late-cut crop (Watson et al. 1937).

Blaxter \& Wilson ( 1963$)$ have estimated output in terms of animal production, taking into consideration the effect of stage of maturity on the yield and nutritive value of hay, and also the effect of digestibility of the hay and concentrate supplementation on the intake of the hays. They concluded that animal production per acre is not proportional to starch equivalent production per acre, and that the optimum stage of maturity for conservation is dependent on the type of animal production 
envisaged. The data show clearly that advice based only on the nutritive value of the herbage or output of dry matter or starch equivalent per acre can be misleading.

\section{REFERENCES}

Allred, K. R. \& Kennedy, W. K. (1956). Agron. F. 48, 308.

Allred, K. R, Kennedy, W. K., Wittwer, L. S., Trimberger, G. W., Reid, J. T. \& Loosli, J. K. (I955). Bull. Cornell agric. Exp. Sta. no. g12.

Armstrong, D. G. (I 960). Proc. int. Grassl, Congr. virs, Reading, p. 485.

Bath, I. H. \& Rook, J. A. F. (1962). Rep. nat. Inst. Res. Dairy., Reading, p. 95.

Blaxter, K. L., Wainman, F. W. \& Wilson, R. S. (r961). Anim. Prod. 3, 5 I.

Blaxter, K. L. \& Wilson, R. S. (1963). Anim. Prod. 5, 27.

Bratzler, J. W., Cowan, R. L. \& Swift, R. W. (1955). Bull. Pa agric. Exp. Sta. no. 597.

Brown, L. D., Hillman, D., Lassiter, C. A. \& Huffman, C. F. (1963). 7. Dairy Sci. 46, 407.

Brown, S. M. (1960). Res. exp. Rec. Minist. Agric. N. Ire. 10, 9.

Brown, S. M. (1962). Agric. N. Ire. 37, I32.

Brown, W. O. \& Smyth, V. (1958). F. agric. Sci. 50, 307

Campling, R. C. (1964). Proc. Nutr. Soc. 23,80 .

Carter, W. R. B. (1960). F. Brit. Grassl. Soc. I5, 220.

Castle, M. E., Drysdale, A. D. \& Watson, J. N. (1 962). F. Dairy Res. 29, I 99.

Culpin, C. (1960). Progr. Rep. exp. Husb. Fms, p. 2.

Culpin, C. (1962). F. Brit. Grassl. Soc. 17, 150.

Culpin, S. (1962). F. Brit. Grassl. Soc. 17, 138.

Dijkstra, N. D. (1947). Versl. landb. Onderz. no. 53.3.C.

Dobie, J. B., Jones, L. G. \& Zscheile, F. P. (1953). Calif. Agric. 7, 413.

Dodsworth, T. L. \& Campbell, W. H. McK. (I953). F. agric. Sci. 43, 166.

Ekern, A. \& Reid, J. T. (r963) F. Dairy Sci. 46, 522.

Ferguson, W. S. (1948). F. agric. Sci. 38, 33 .

Ferguson, W. S. \& Terry, R. A. (1957). F. agric. Sci. 48, 149.

Geering, J. (1939). Schweiz. landw. Mh. 17, 39.

Gordon, C. H., Decker, A. M. \& Wiseman, H. G. (1962). Agron. F. 54, 346.

Gordon, C. H., Derbyshire, J. C. \& Jacobson, W. C. (1963a). F. Dairy Sci. 46, 63o.

Gordon, C. H., Derbyshire, J. C., Jacobson, W. C. \& Wiseman, H. G. (1963b). F. Dairy Sci. 46, 41 I.

Gordon, C. H., Derbyshire, J. C., Wiseman, H. G., Kane, E. A. \& Melin, C. G. ( I96r). J. Dairy Sci. $44,1299$.

Gordon, C. H., Irvin, H. M., Melin, C. G., Wiseman, H. G. \& McCalmont, J. R. (I957). F. Dairy Sci. 40, 789 .

Gordon, C. H., Kane, E. A., Derbyshire, J. C., Jacobson, W. C., Melin, C. G. \& McCalmont, J. R. (1959). F. Dairy Sci. 42, I703.

Harkess, R. D. (1963). F. Brit. Grassl. Soc. 18, 62.

Harris, C. E. \& Raymond, W. F. (1963). F. Brit. Grassl. Soc. 18, 204.

Head, M. J. (1953). F. agric. Sci. 43, $28 \mathrm{I}$.

Hood, A. E. M. (1957). भ. agric. Sci. 48, 143.

Horwood, R. E. \& Wells, J. G. (1936). Quart. Bull. Mich. agric. Exp. Sta. 19, 100.

Kon, S. K. \& Thompson, S. Y. (1940). F. agric. Sci. 30, 622.

McCarrick, R. B. (1963). Proc. Grass Conservation Conf., p. 195. Dublin: An Foras Talúntais.

Minson, D. J. (1962). Contr. Anim. Res. Inst., Ottawa, no. 84.

Minson, D. J., Raymond, W. F. \& Harris, C. E. (1960). F. Brit. Grassl. Soc. 15, I 74.

Monroe, C. F., Hilton, J. H., Hodgson, R. E., King, W. A. \& Krauss, W. E. (1946). J. Dairy Sci. 29, 239.

Moore, L. A., Thomas, J. W. \& Sykes, J. F. (I960). Proc. int. Grassl. Congr. viII. Reading, p. 70I.

Morrison, J. (1960). Proc. int. Grassl. Congr. viII. Reading, p. 693.

Murdoch, J. C. (1954). Agriculture, Lond., 6r, 224.

Murdoch, J. C. (1960). F. Brit. Grassl. Soc. 15, 70.

Murdoch, J. C. (1961). I. Brit. Grassl. Soc. 16, 253.

Murdoch, J. C. (1962a). Rep. nat. Inst. Res, Dairy., Reading, p. 32.

Murdoch, J. C. (1962b). F. Brit. Grassl. Soc. 17, 133.

Murdoch, J. C. $(1962 c)$. F. Brit. Grassl. Soc. 17, 268.

Murdoch, J. C. \& Bare, D. I. (1960). F. Brit. Grassl. Soc. 15, 94.

Murdoch, J. C., Foot, A. S., Head, M. J., Holdsworth, M. C., Hosking, Z. D. \& Line, C. (1959). F. Brit. Grassl. Soc. 14, 247.

Murdoch, J. C. \& Holdsworth, M. C. (1958). F. Brit. Grassl. Soc. 13, 55.

Murdoch, J. C. \& Rook, J. A. F. (1963). F. Dairy Res. 30, 39 I. 
Murdock, F. R., Hodgson, A. S. \& Harris, J. R. (1958). Proc. W. Div. Amer. Dairy Sci. Ass. p. I65.

Newlander, J. A., Ellenberger, H. B., Camburn, O. M. \& Jones, C. H. (1940). Bull. Vt agric. Exp. Sta. no. 459 .

Newlander, J. A. \& Riddell, W. H. (I957). Bull. Vt agric. Exp. Sta. no. 602.

Nowakowski, T. Z. (1962). F. agric. Sci. 59, 387.

Perkins, A. E. \& Pratt, A. D. (1951). F. Dairy Sci. 34, 606.

Pratt, A. D. \& Conrad, H. R. (1957). F. Dairy Sci. 40, 620.

Pratt, A. D. \& Holdaway, C. W. (I943). Bull. Va agric. Exp. Sta. no. 353.

Presthegge, K. (1959). Norg. Landbrukshøisk. Beretn. ForForsøk. no. 93 .

Reid, J. T., Kennedy, W. K., Turk, K. L., Slack, S. T., Trimberger, G. W. \& Murphy, R. P. (1959). F. Dairy Sci. 42, 567 .

Rook, J. A. F. (г96r). Dairy Sci. Abstr. 23, 25 I.

Sears, P. D. \& Goodall, J. C. (1 947). N.Z.F. Sci. Tech. A, 28, 289.

Shaw, J. C. (1959). Agron. F. 51, 242.

Shepherd, J. B., Wiseman, H. G., Ely, R. E., Melin, C. G., Sweetman, W. J., Gordon, C. H., Schoenleber, L. G., Wagner, R. E., Campbell, L. E., Roane, G. D. \& Hosterman, W. H. (1954). Tech. Bull. U.S. Dep. Agric. no. Io79.

Shepperson, G. (1960). Proc. int. Grassl. Congr. viIr. Reading, p. 704.

Shepperson, G., Grundey, J. K. \& Wickens, R. (1962). Exp. Husb. no. 8, p. 65.

Slack, S. T., Kennedy, W. K., Turk, K. L. \& Boyce, O. A. (1960a). Bull. Cornell agric. Exp. Sta. no. 950.

Slack, S. T., Kennedy, W. K., Turk, K. L., Reid, J. T. \& 'Trimberger, G. W. (I960b). Bull. Cornell agric. Exp. Sta. no. 957.

Thomson, D. J. (1963). Exp. Grassl. Res. Inst., Hurley, no. 15, p. 48.

Trimberger, G. W., Kennedy, W. K., Turk, K. L., Loosli, J. K., Reid, J. T. \& Slack, S. T. (1955). Bull. Cornell agric. Exp. Sta. no. 910.

'Turk, K. L., Morrison, S. H., Norton, C. L. \& Blaser, R. E. (1951). Bull. Cornell agric. Exp. Sta. no. 874 .

Watson, S. J., Ferguson, W. S. \& Horton, E. A. (1937). J. agric. Sci. 27, 224.

Watson, S. J. \& Nash, M. J. (Ig60). The Conservation of Grass and Fodder Crops. Edinburgh: Oliver $\&$ Boyd.

Wiegner, G. (1932). Schweiz. landw. Mh. 10, 145 . 